\title{
Reflections on the history and legacy of scientific racism in South African palaeoanthropology and beyond
}

\author{
Rebecca Rogers Ackermann \\ Human Evolution Research Institute, Department of Archaeology, University of Cape Town, South Africa \\ [published in the Journal of Human Evolution https://doi.org/10.1016/j.jhevol.2018.11.007]
}

\author{
Darwin's Hunch: Science, Race and the Search for Human Origins \\ By Christa Kuljian (2016). Jacana Media (Pty) Ltd, Auckland Park, South Africa, 352 pp., R295.00/\$24.95 \\ (paperback). ISBN 978-1-4314-2425-2.
}

\section{Introduction}

The history of scientific discovery is overwhelmingly told as a narrative of the lives and discoveries of a series of remarkable white men. Christa Kuljian's real triumph in this book is that she reframes the narrative of palaeoanthropological discovery in South Africa as a tale of flawed men who succeed-through some combination of luck, skill, personality and perseverance-literally and figuratively on the backs of black bodies. That she tells this story with limited cynicism and anger is a testament to the author. This book takes a rich, personal, archivally-intensive and interview-based look at the history of palaeoanthropology that is uncommon in our field, focussing on a region of the world where the global context of racism and the eugenics movement in the $20^{\text {th }}$ century was further compounded by state-sanctioned apartheid. It is a timely tale of racism and misogyny and how they shape scientists, the scientific enterprise, and narratives of human origins and evolution. Although a large portion of this book is historical, it brings the reader right up to the present, and contains themes that remain relevant today, in the age of \#BlackLivesMatter, \#MeToo, and other pertinent movements, and affect our field more generally.

In this review, I will first provide a very brief summary of the book. I will then highlight what I believe are the book's most salient themes that are relevant to biological anthropology today: racism in science, intersectionality, and the invalid (but still prevalent) idea that scientists and their work can be separated. Finally, I will consider current practice in palaeoanthropology, as well as various reviews of the book, in order to reflect on these issues. ${ }^{1}$

\footnotetext{
${ }^{1}$ Note on racial terminology in South Africa: black (lowercase b) will be used to refer to all people of colour, while Black (uppercase B) is reserved for the subset of black people of Bantu-language speaking descent (also called Black Africans). Other groups subsumed within the South African category black include Coloured and Indian. Coloured can include mixed-race people or people of Khoesan descent. This current terminology differs somewhat from the four race categories (White, Black, Coloured, Indian) implemented under apartheid.
} 


\section{Brief summary}

Kuljians' book is divided into three parts, organized chronologically, and roughly corresponding to pre, during and post-apartheid. The first part (Chapters 1-8), titled "Searching for difference," begins with Kuljian arguing that Darwin's reasoning that our early ancestors came from Africa (i.e. "Darwin's hunch") was part of a broader context that intertwined the search for human origins with the search for primitive people (e.g., searching for the 'other' or 'difference'), searches that played out in a highly racialized context. This section focusses largely on the first half of the $20^{\text {th }}$ century, and serves to flesh out a major focus of this book - that anatomists with palaeoanthropological interests (such as Robert Broom, Raymond Dart, and later Philip Tobias) were at the forefront of this intersection of evolution and scientific racism. South Africa was uniquely positioned in some respects because of the key role indigenous South Africans, in particular, played in this narrative globally; scientific interest in human origins of the time was highly influenced by European scientists interested in the possibility that humans such as 'Bushmen' (i.e., Khoesan) might represent the 'missing link' between apes and humans. Implicit in this approach is the notion that these local indigenous (black) people are by definition considered primitive and therefore less human than other (white) humans. After setting up this theme, Kuljian spends much of the rest of the first section detailing the practices of Broom, Dart and others in South Africa, especially how collecting fossils, the remains of 'primitive' people, and other biometric data, played into this racial narrative both locally and internationally. This includes discussion of how this racial science tracked with the changing political landscape of South Africa as it moved from a colonized country, through minority rule by white South Africans and the politically formalized and socially enforced racial segregation of the 1930s, and ultimately the adoption of apartheid as formal policy by the government after the election of the National Party in 1948.

Although the second part of the book, "Searching for humanity" (Chapters 9-17), which focusses on the 1950s through 1980s, details a somewhat less overtly racist period for science globally (and considerable discussion about the meaning, or lack thereof, of race), nonetheless race and racism continued to thread their way through the science of the time. This was especially true in South Africa, where the apartheid regime was in full force. ${ }^{2}$ In this section, Kuljian introduces a number of new characters, demonstrating the changing academic landscape within a highly volatile South African (and global) sociopolitical landscape. She begins by chronicling the shifting dynamics in the 1950s which lead to the global emergence of a less typological physical anthropology. In South Africa, Kuljian argues that researchers such as Hertha de Villiers, Ronald Singer, and to a lesser extent Phillip Tobias (who was previously, and continued to be, involved in expeditions to measure/cast 'native' people), were at the forefront of this movement. Tobias is a particularly complex case, as his early work was "steeped in Dart's typological paradigm" (p. 117), and Kuljian repeatedly points out that the process of separating himself from scientific racism was a drawn out (but ultimately successful) one, which involved trying to synch his scientific practices around studying race in apartheid South Africa with the growing feeling in parts of academia that races were not biologically real. Ultimately,

\footnotetext{
${ }^{2}$ Apartheid lasted from 1948 to 1990 . Soon after the formalization of apartheid, various laws were passed to formalize segregation through the prohibition of mixed marriages and relationships, implementation of pass laws, and classification all South Africans into one of four racial groups (Black, White, Coloured, and Indian), among other things. Places of residence were then determined based on these classifications. The 1960s, 1970s, and early 1980s, were marked by forced removals of people into segregated neighbourhoods and 'bantustans' (tribal homelands) to further solidify racial and social separation. Internal resistance to apartheid grew increasingly violent in the 1970s and 1980s, and along with other resistance, including international pressure, ultimately led to bilateral negotiations between the ruling National Party and the African National Congress, and the repeal of apartheid legislation starting in 1991.
} 
due in part to a long-term relationship that became established between Tobias and the Leakeys in the late 1950s and early 1960s, Tobias' work shifted away from living people and towards fossils, and he ultimately became an anti-apartheid activist. The final chapters in this section cover the ongoing work of Phillip Tobias, Trefor Jenkins, Ron Clarke, Bob Brain, Elisabeth Vrba, Alan Morris, Hertha de Villliers and visitors such as Bernard Wood, up to and during the 1970s, a time that Kuljian describes as the transition from a typological to a more contextual approach, within a highly volatile political landscape. However, it is made clear that despite this intellectual transition, nonetheless the practice of white people studying predominantly black people had been well-established and persisted. Kuljian also (e.g., Morris and Wood) highlights the continuation of a pattern that started with Broom and Dart-i.e., white foreigners coming to South Africa to study South African heritage-both fossils and the skeletons of modern Africans-and the reality that despite the contributions of people like De Villiers and Vrba, this continued to be predominantly a man's game.

The third section, "Searching for unity" (Chapters 18-27), covers the period from the late 1980s, when DNA studies provided evidence that all living humans share a recent African mitochondrial ancestor, to the time when the book went to press. In the first part Kuljian covers Himla Soodyall (black, female) and her emergence as part of a new generation of South African researchers; immigration of Lee Berger from the U.S. and his ultimate appointment as Tobias' successor as head of his research unit following Tobias' retirement in 1996; the return of Ron Clarke and escalating tensions between him and Berger; the retirement of Tobias and Brain; emigration of Vrba to the U.S.; establishment of the funding body PalaeoAnthropological Scientific Trust (PAST; now the Palaeontological Scientific Trust); and other events that marked this period in South African palaeoanthropology. This all, of course, happened around the time of the transition to a democratic South Africa in 1994. Note that this is also the time when I first came to South Africa, initially doing PhD research on the australopiths in 1995 and 1996, and eventually immigrating in 2000. For the remainder of the book, Kuljian weaves narratives of repatriation, fossil discovery, personality conflicts, and transformation (the ongoing process of rectifying the racist policies of the past through changing to a representative, majority black, demographic in the workplace at all levels), to show how South Africa is transitioning to the present in the context of the 'new South Africa,' and the societal mandate of a less-racialized space. This is, however, a fairly rocky transition. For example, Kuljian discusses the presentday lack of black academics in palaeoanthropology/archaeology as a whole in South Africa, a topic I will return to later. Kuljian also tackles the complexities of who owns and/or controls heritage, especially the needs/desires of scientists, government, regional and local chiefs, and of course the people on the ground, who often get left out or marginalised without any of the benefits of heritage sites and research accolades accruing to their communities. This section ends with the well-publicized, social media-driven discovery, excavation and analysis of the hominin remains from Dinaledi chamber in the Rising Star cave system, and the controversy-both scientific and political-around the finds.

\section{South African palaeoanthropology was (is?) racist}

As Jon Marks recently wrote in his pithy little book titled "Is Science Racist?", "Science is racist when it permits scientists who advance racist ideas to exist and to thrive institutionally" (Marks, 2017:3). By this definition, the thesis that South African palaeoanthropology was racist-particularly in the late 1800 s and early 1900s, but also closer to the present-is well demonstrated and is the key unifying theme of Kuljian's book. The idea that biological anthropologists and other scientists during this time period practiced racist science is not new (e.g., Dubow, 1995; Gould, 1996; Wolpoff and Caspari, 1997; Sussman, 2014; Marks, 
2017), but what Kuljian does that stands out from other work is to provide a wealth of archival and personal detail documenting how this played out in a localized South African context, illuminating the racialized space (with often politically sanctioned racist agendas) out of which South African palaeoanthropology grew. Many of the practices of the past that Kuljian describes, such as genital measuring or grave robbing, are abhorrent to us today. That is the literal part of the "standing on the backs of black bodies" that I alluded to in the introductory paragraph. Researchers used black people as their laborers and as their subjects; the treatment of black women was particularly egregious.

The book also, almost subversively, succeeds in demonstrating how even in the face of changing individuals and ideologies over time, nevertheless the legacy of a racist past remains stitched into the fabric of the present (i.e., systemic or structural bias) in South Africa, affecting the science of palaeoanthropology in lingering ways. This is the figurative part of the "standing on the backs of black bodies." This legacy affects the science we practice, how we practice it, who does the practising, and who wants to do the practicing. The reality is that even good, well-meaning scientists can perpetuate racism if they are working in a system that has been shaped by long-term colonial practices that legalized racism, such as that experienced in apartheid South Africa.

One example that links early racist science to the present is the legacy of human remains collections. Based in part on a visit to Washington University in St. Louis, where he worked with Robert Terry (of Terry Collection fame), Dart began a similar collection at the University of the Witwatersrand (Wits). This ultimately resulted in Wits being a repository of a vast collection of human skeletal remains of primarily black South Africans, the Raymond A. Dart Collection of Human Skeletons, still studied to this day. Kuljian describes Dart's quest-like many of his time-to find 'pure' South African 'racial types' for his collection; early on, some of the skeletons were taken from graves, while others were unclaimed bodies from hospitals that were macerated for the collection. Soon after, research into the so-called distinguishing characteristics of racial types proliferated in South Africa, as work on these collections increased (much like on comparable collections overseas). As Kuljian discusses, this racial typology also fit well into the politics of South Africa at the time; scientific racism merely served to justify the policies of what would ultimately become apartheid. Today, although many of the unethically collected remains are no longer accessible for scientific research, nonetheless researchers still work on the bulk of these materials, at Wits and other institutions that are often still racially segregated in terms of who controls the collections, and who cleans the floors. Meanwhile, there is a growing debate within the South African museum community, and beyond in the public and political sphere, about whether such collections should still be studied, or rather repatriated (Rassool, 2015). What distinguishes this from comparable debates in places like the USA and Australia is the dynamics of the discourse given the history of apartheid, and especially the reality that the previously oppressed constitute a numerical and political (if not monetary) majority.

\section{Intersectionality}

Kuljian comes across in this book as a staunch feminist, not because she interjects herself into the book (much), but because she is careful to highlight marginalised voices and especially intersectional identities and bring out their stories as much as possible. Nowhere does this stand out more than in her consideration of the stories of black women. For example, Kuljian relates the story of /Keri-/Keri, a young woman who was the granddaughter of the patriarch of a group of indigenous people in Tweerivieren (250 $\mathrm{km}$ north of Kimberley), and an individual prized by the scientists as representing a 'pure' type, her death, 
and the acquisition of her body by Dart for his collection. Kuljian's search for the story of /Keri-/Keri, her remains, and her life mask are central in humanizing this book, as she represents every person-and especially every black woman - who was exploited in the making of the scientific careers of the people who studied her, not unlike the iconic Sarah Baartman did more than a century before (and whose remains were eventually returned to and reburied in South Africa in 2002 after extensive negotiations with the French authorities, a process led by Tobias-a topic Kuljian also covers).

As another example, in addition to skeletons and face masks, Dart and his contemporaries also collected other morphological data including physical measurements such as skin colour, face shape, head shape, and limb length, with special attention (like others of his time) to external genitalia and secondary sexual characteristics of black women in particular. Kuljian discusses how scientific analyses and descriptions derived from these data were used to characterize races, the so-called immature child-like morphology (paedomorphosis) of the Khoesan, and sexual deviance (relative to Europeans). Later, direct labia measurements were taken by Tobias, De Villiers and their Wits colleague Trefor Jenkins, in 1959, 1961, and 1964 , respectively. Kuljian goes into considerable detail about the measurement of female labia minora ('tablier'), and her description of this is worth quoting in full; it makes for some tough reading, but highlights the intersection of racism and sexism in important ways:

"In carrying out her study, De Villiers had gone to Baragwanath Hospital in Soweto, south west of Johannesburg. The women she met there were either ill or in wards, or waiting for attention in the out-patient department or at the ante-natal clinic. All of these women were living in oppressive conditions in apartheid South Africa. They had to carry passes. Many of them had to travel long distances every day to work in the homes of white people as domestic servants. There is no documentation of how these women reacted when a scientist asked to measure their labia, nor is it recorded whether they were paid to participate or coerced. De Villiers asked each woman to stand up with her legs slightly apart. She placed a sliding caliper gently on the labia minora at the point of emergence. Keeping the caliper in position, she shifted the moveable point of the caliper down to the lowest point of the labia." (p. 148)

Kuljian further quotes De Villiers directly: "Amongst Bushman women, it is fairly common practice to conceal the labia minora within the vagina, resulting in a swollen and puffed appearance of the labia majora pudenda. In measuring, it is necessary, therefore, to ensure that the labia have been completely extracted and are hanging freely" (Kuljian, 2016:148).

These passages, and Kuljian's approach more generally, powerfully juxtapose the marginalised and the privileged as a means for understanding how layered identities fared in these spaces. Although certainly body collection and measuring, especially of marginalised people but also the powerless (e.g., nude posture photos of students; Rosenbaum, 1995), was prevalent in other places around the world, I would argue that the extreme state-sanctioned racism of apartheid South Africa likely emboldened these practices, freeing privileged white people to explore their 'interests' in a more extreme or purer form. Racist science benefitted them both academically and socially. Moreover, both the study of genitalia itself and potential coercion are morally problematic in a context where black people were rendered lesser citizens and disempowered by government decree.

Kuljian's consideration of intersectionality also comes across when discussing the intellectual and personal trajectories of the scientists. For example, Tobias ultimately transitioned from the role of participant in racist practises to a voice for the oppressed (activist, vocal proponent of the narrative of African origins, proud producer of thousands of black students), which, while complicated and not without struggle, was perhaps not surprising given that he was from a somewhat marginalised, intersectional 
background himself (e.g., gay, Jewish). De Villiers was another complex character. Like other scientists of her time, she was moving intellectually away from typology (including the typology of race) given the changing scientific narratives around race in the 1950s and 1960s, and yet remained steeped in the lingering racist practices of her work in apartheid South Africa, unable to fully separate from the systemic bias that was so pervasive (as discussed above). De Villiers also struggled to reconcile her position as a female researcher practicing racist science against women in particular with the more personal reality (that she long denied) that her adopted daughter was black. These examples highlight another important theme of the book, one I will consider next-the inseparability of the (human, flawed, sociopolitically influenced) scientist from the science.

\section{Science vs. scientist}

One of the real strengths of this book is that Kuljian unabashedly frames science through the lens of an externalist perspective. Even Kuljian's approach of gaining perspectives through interview speaks to this externalist take on science. Briefly, in the historiography of science, internalism makes the case that science is immune from social influences (and that there is such a thing as pure natural science), while externalism takes the view that sociopolitical forces (including economic ones) determine scientific progress, and therefore that science is inseparable from its social context (Fuller, 2000, and references therein). Externalist and internalist perspectives play out very differently in practice. An internalist perspective on science places relatively higher value on scientific process and content, meaning that the duty to the science is perceived as higher than the duty to the discipline or broader culture in which we act and live. It tends to align with Western, male and traditional (conservative) interests, as science does, and as a result reinforces status quo and its power relations. Scientific outputs such as data and academic papers are considered reports of activity and are perceived to be separate from (and unrelated to) personal or cultural context. I am willing to bet that most of the researchers highlighted in this book see/saw their science and its outputs through a largely internalist lens; what they were doing-even the horrid things-seemed completely appropriate to them in their quest for knowledge. In contrast, an externalist perspective places relatively higher value on science as an institution and the place and meaning of that institution in society. The entire scientific endeavor, including all the outputs of that endeavor, is the product of human activity. It is therefore by definition suffused with personal identity, ethics and politics-it cannot be otherwise.

Relating this to Kuljian's book, her telling of this South African story clearly illustrates that the personalities of individual researchers, their beliefs, practices and choices, and how these manifested in the sociopolitical context of South Africa, are all relevant to the science. Through this lens, the products of this science are inseparable from their context; this includes products such as the Raymond A. Dart Collection of Human Skeletons, but also the research itself. Indeed, in some cases the links Kuljian makes between science, scientist, and society are all too clear: for example, the Prime Minister of the coalition government, Jan Smuts, supported the research of Robert Broom, and secured a position for him at the Transvaal museum (now Ditsong Museum), in large part because the study of human evolution was supporting racial differences and the superiority of Europeans relative to the 'natives.' From this externalist perspective, these scientists benefited directly from what they did (the good and the bad) because their behaviours resulted in benefits to them that reinforced their position of power in the system. That power was academic, but also political and financial. In a system that is as biased and discriminatory as apartheid South Africa, their success and their science cannot be divorced from this bias. White men had the most power and privilege because of their value to society; as a result they accrued the most benefits, framed the direction of the 
science, and controlled the narrative (see also Athreya and Ackermann, 2018). The handful of white women scientists who are covered in this book (e.g., De Villiers, Vrba) also benefitted from their power and privilege, albeit to a lesser extent as there were fewer of them, they had to contend with systemic bias against women, and they therefore had relatively less power. I am acutely aware that I, personally, benefit from the legacy of this system and the fact that there were no appropriately qualified South African biological anthropologists to hire in $\mathbf{2 0 0 0}$ when I took up my post here. So do all white people who work in South Africa today.

\section{The new South Africa?}

In the last section of her book Kuljian begins a conversation about the demographics of South African palaeoanthropology today, and refers to an article by Alan Morris where he uses the composition of the authors of the Australopithecus sediba discovery to highlight the lack of transformation in the discipline (Morris, 2011). In the two and a half decades since the end of apartheid and the beginning of democracy numerous practices and policies have been put in place to encourage transformation across academic institutions; nevertheless the racial demographics have shifted very little, despite this being a majority black country that has transformed in other sectors to varying degrees. Importantly, this demonstrates how the legacy of past practices continue to affect who controls the science and shapes the narratives of human evolution. For example, since the 2010 papers Morris was referring to, easily the most prominent academic article to come out of South African palaeoanthropology was the 2015 announcement of the new species Homo naledi by Berger et al. (2015), which was an international sensation. In that paper, the demographics of the authorship were as follows: of the forty-seven authors, six were South African, of whom two are foreign-born, naturalised South Africans (Berger and myself, both white), two are white men (Kruger, Zipfel), and two are black (Nalla, Schroeder). The 2017 paper of the newest remains (Hawks et al, 2017) showed progress in this regard, but still had only eleven (out of 38) South Africans, of whom four were black and the rest white men. This does not diminish the importance of the finds, but it does illustrate that the field is still far from transformed.

Kuljian also describes how in the early part of last century the young black men who did the technical work in the field and museums were often unnamed in publications, typically referred to only by their first names or 'boy', and as a result with little known about most of them today. These practices are thankfully long gone. Yet even now, the staff profile of the Evolutionary Studies Institute at Wits (https://www.wits.ac.za/esi/staff/) shows that of the eighteen academics listed all but one are white (Kibii being included as an honourary researcher, though he is now employed full time at the National Museums of Kenya). In contrast, if you look at the technical staff, they are predominantly black. Only a handful of these are black women, speaking to the continuation of the compounded issue of intersectionality (black, female) I discussed above. This illustrates that structural racism persists to this day at the institution that is the focus of Kuljian's book, the primary training ground for palaeoanthropology in South Africa, and the repository for the bulk of South Africa's hominin fossil heritage. These are prominent examples of the ongoing problem we have in South African palaeoanthropology with transformation, but they are not the only examples. Indeed, at my institution, the University of Cape Town, where palaeoanthropology is taught in the Archaeology Department, although we have a better faculty demographic (currently 50\% black, 50\% female), UCT's Science Faculty as a whole does not have a single South African Black female full professor. 
Encouragingly, there are considerably more black (and Black) postgraduate students than there used to be (especially in the last decade) in South Africa, but this has yet to translate into them going into academia in meaningful numbers; we need to look closely at the reasons for this. Yes, it is true that there are not many job openings. But I would suggest that the systemic biases that are specific to our disciplinebiases that stem from the racist/sexist past but are still strongly embedded in the fabric of palaeoanthropology -are also a contributing factor in holding people back and/or turning people off. Students who might be interested in the discipline could experience these biases in numerous ways-as direct recipients of racism (and/or sexism), as witnesses to racist practices, or because they do not feel welcome in this segregated context. Moreover, racist and sexist perspectives remain embedded in scientific practice and the canon of scientific knowledge we teach (Athreya and Ackermann, 2018), which may serve to further alienate students.

These issues of representivity are not unique to South Africa. For example, the USA also has very poor 'minority' representation in the higher echelons of biological anthropology (Antón et al., 2018)-but again, in South Africa black people are a vast majority, not a minority. Both the obligations and expectations for transformation are much higher in a South African context, where discussions across all sectors on how to rectify the discriminatory practices of the past and make reparations have been ongoing for decades, and have escalated in recent years. Privileged spaces such as academia have been relatively slow to change, especially at the higher ranks, despite a realisation that they are in need of decolonisation (e.g., \#RhodesMustFall). That is why the lack of transformation in palaeoanthropology is especially problematic; it damages the discipline politically and financially, and is morally inexcusable.

\section{Beyond South Africa}

Although the history and politics of South Africa do make the situation far more systemic, nonetheless these issues are not unique to South Africa. The legacies of our racist past remain stitched into the fabric of the present not just in South African paleoanthropology, but also in African palaeoanthropology more broadly (as well as paaleoanthropology, biological anthropology and science more broadly). For example, in 2016, the National Museums of Kenya (NMK) honoured African fossil hunters in a two-day international event dubbed "Celebrating Africa's Unsung Heroes in Prehistory Research", and while this was a clear and welcome acknowledgement of the contributions of all the black people to the academic successes of researchers who are overwhelmingly foreign and white, it nonetheless highlighted that the majority of the academics involved (and attending the event) continue to be the latter. Anyone who has participated in palaeoanthropology fieldwork on the continent has observed a similar pattern of majority white academics and majority black field workers in many contexts, an unfortunate continuation of racially segregated spaces from the past. There have been some inroads to changing this, with black senior academics in positions of leadership at NMK, Ditsong Museum, and other institutions, and a few high profile black African paleoanthropologists employed at institutions abroad, but it has been a relatively small shift when considering the field as a whole. This also highlights how the structural problems we have in South Africa (and other African countries) are not just perpetuated by the practices of South Africans (Africans); because the resources are valuable to the international community, international researchers are complicit in propping up these inequalities. How often do international researchers from the USA or Europe come for research visits, study fossil hominin material, and never engage intellectually with a black African peer? How many give substantial workshops or seminar series, spending quality interactive time with black students 
and researchers? More than once I have heard international colleagues say that they just barely have enough time to study the fossils and cannot stay a day longer.

There is a potent scene in the film Black Panther (2018) where Killmonger visits a museum collection with African artefacts, that highlights myriad issues around heritage, who owns it, and who is best placed to interpret it. This issue comes across many times in Kuljian's book (though she is primarily focussed on who owns actual physical human remains, the families or the scientists) and is too frequently an undertone in the practices of Western researchers as well. It is well-known in palaeoanthropology (and archaeology) that there are foreign researchers who claim a certain level of ownership over, and rights to study (and exclude others from studying), African material they have excavated. Researchers need to think carefully about the implications and possible repercussions of such practices; not only are they morally and ethically problematic, but they undermine our transformation efforts, and could ultimately lead to pushback and especially reclamation and repatriation of even the most ancient of hominin remains.

\section{Conclusions}

Historical and social studies of science are not neutral, value-free and outside of politics, and as a result morality plays an important role in how scientists conduct themselves (Marks, 2017). This is an important take-home lesson from Kuljian's book (and Marks, 2017). It is also a message that many other reviews of 'Darwin's Hunch' in the South African press have highlighted as they focus (to varying degrees) on her insights into the interrelation of science, politics and racism, and the importance of this book for reflecting on the moral consequences of our actions in the past, and in the present (Lang, 2017; Mal, 2017; Mokoena 2017; Morris, 2017; Rossouw, 2017; Willis, 2017). Interestingly, all of the reviews by South Africans to date are positive, often enthusiastic, with many highlighting its potential role in conversations on decolonising science, while the one (to date) international review is lukewarm (Wood, 2018), and fails to engage substantially with the crux of Kuljian's thesis-that palaeoanthropology was, and in some respects continues to be, racist. This is a striking contrast, one that I believe reflects the discordance between a very externalist acceptance by most South Africans that scientists and their science are often profoundly shaped by sociopolitical context, and (they) bear moral responsibility for those actions and (us) for their consequences, versus a very internalist Western perspective that views the narrative of this book as merely a historical work and a product of a problematic past (where scientists lived in very different times and sometimes got too close to politics), but not a reflection on the quality of their research, or on science and scientists then or today. Of course, not all scientists in the West adhere to an internalist perspective, and externalist approaches are increasingly being taken by younger generations of scientists and scholars who bring other marginalized/intersectional perspectives to their work, but nevertheless this internalist lens remains prevalent.

Much like Kuljian argued for the interconnectedness of human origins research and scientific racism in palaeoanthropology at a local scale, Athreya and Ackermann (2018) have recently argued that even at a global scale, the broader discourse around human origins narratives was, and importantly continues to be, shaped by sociopolitical factors that otherize and marginalise people of colour. The resultant lack of diversity has affected the content of the science, hindering the production of a robust and unbiased narrative of human origins (Athreya and Ackermann, 2018).

Yet there is a general lack of self-reflexivity in our field around the lingering effects of colonialism and imperialism, and a subsequent lack of consideration of how racism remains baked into not only the structure 
and practices of the discipline, but the content of the science (Athreya and Ackermann, 2018). Because of this, I challenge researchers from overseas, including (but not limited to) those who come to do research on the precious heritage of South Africa, to read this book, learn about the past that has resulted in the collections, and reflect on the still racially (and to a lesser extent gender) stratified academic/technical/field enterprise. The treatment of South African bodies is as much a part of the dark legacy of biological anthropology as is the contemporaneous collection/treatment of Native Americans, African Americans, and others, yet receives considerably less attention due to the predominantly Western, heavily USA-centric demographics of the discipline. Biological anthropologists will benefit from the insight this book can provide, and through self-reflection and subsequent action, can work to shape a future that is welcoming to everyone.

\section{Acknowledgements}

I thank Denne Reed for working with me to get this manuscript published. David Alba, Sheela Athreya, Jon Marks, Mike Plavcan, Lauren Schroeder, and two anonymous reviewers provided thoughtful comments on drafts of this manuscript, for which I am grateful. Funded by the DST/NRF Centre of Excellence in Palaeosciences (CoE-Pal) and the National Research Foundation of South Africa.

\section{References}

Antón, S.C., Malhi, R.S., Fuentes, A., 2018. Race and diversity in U.S. Biological Anthropology: A decade of AAPA initiatives. Yearbook of Physical Anthropology 165 S65, 158-180.

Athreya, S., Ackermann, R.R., 2018. Colonialism and narratives of human origins in Asia and Africa. In: Porr, M., Matthews, J. (Eds.), Interrogating Human Origins: Decolonisation and the Deep Past. Routledge, Abingdon. https://doi.org/10.31730/osf.io/jtkn2

Berger L.R., Hawks J., de Ruiter, D.J., Churchill, S.E., Schmid, P., Delezene, L.K., Kivell, T., Garvin, H.M., Williams, S.A., DeSilva, J.M., Skinner, M., Musiba, C.M., Cameron, N., Holliday, T.W., Harcourt-Smith, W., Ackermann, R.R., Bastir, M., Bogin, B., Bolter, D., Brophy, J., Cofran, Z.D., Congdon, K.A., Deane, A.S., Dembo, M., Drapeau, M., Elliott, M., Feuerriegel, E.M., Garcia-Martinez, D., Green, D.J., Gurtov, A., Irish, J.D., Kruger, A., Laird, M.F., Marchi, D., Meyer, M.R., Nalla, S., Negash, E.W., Orr, C.A., Radovcic, D., Schroeder, L., Scott, J.E., Throckmorton, Z., Tocheri, M.W., VanSickle, C., Walker, C.S., Wei, P., Zipfel, B., 2015. Homo naledi, a new species of the genus Homo from the Dinaledi Chamber, South Africa. eLife 4, e09560.

Black Panther, 2018. Marvel Studios (distributed by Walt Disney Studios Motion Pictures), United States, feature film, 134 minutes.

Dubow, S., 1995. Illicit Union: Scientific Racism in Modern South Africa. Cambridge University Press, Cambridge.

Hawks, J., Elliott, M., Schmid, P., Churchill, S.E., De Ruiter, D.J., Roberts, E.M., Hilbert-Wolf, H., Garvin, H.M., Williams, S.A., Delezene, L.K., Feuerriegel, E.M., Randolph-Quinney, P., Kivell, T.L., Laird, M.F., Tawane, G., DeSilva, J.M., Bailey, S.E., Brophy, J.K., Meyer, M.R., Skinner, M.M., Tocheri, M.W., VanSickle, C., Walker, C.S., Campbell, T.L., Kuhn, B., Kruger, A., Tucker, S., Gurtov, A., Hlophe, N., Hunter, R., Morris, H., Peixotto, B., Ramalepa, M., van Rooyen, D., Tsikoane, M., Boshoff, P., Dirks, P.H.G.M., Berger, L.R., 2017. New fossil remains of Homo naledi from the Lesedi Chamber, South Africa. eLife, e24232. 
Fuller, S., 2000. Internalism versus externalism. In: Hessenbruch, A. (Ed.), Reader's Guide to the History of Science. Routledge, London, pp. 380-381.

Gould, S.J., 1996. The Mismeasure of Man, second edition. W.W. Norton \& Company, New York.

Lang, S., 2017. Our ancestors in Africa. Grocott's Mail, 04 August. http://christakuljian.com/wpcontent/uploads/2017/09/GM0428_SMALL1.pdf

Mall, A.S., 2017. Book review: Darwin's hunch: science, race and the search for human origins. South African Medical Journal 107, 653.

Marks, J., 2017. Is Science Racist? Polity Press, Cambridge.

Mokoena, H.. 2017. The perversion of paleontology by apartheid's advocates still lingers. The Conversation, 08 June. https://theconversation.com/the-perversion-of-paleontology-by-apartheids-advocates-stilllingers-78617

Morris, A., 2011. On human evolution, Australopitheus sediba and nation building. South African Journal of Science 107, \#957.

Morris, A., 2017. Human evoluton and South African science: Darwin's hunch in context. South African Journal of Science 113, \#a0231.

Rassool, C., 2015. Re-storing the skeletons of empire: return, reburial and rehumanisation in Southern Africa. Journal of Southern African Studies 41, 653-670.

Rosenbaum, R., 1995. The great Ivy League nude posture photo scandal. The New York Times Magazine, Sunday 15 January, 6006026.

Rossouw, R., 2017. Book review: Darwin's hunch: science, race and the search for human origins. Business Day, 03 January. https://www.businesslive.co.za/bd/life/books/2017-01-03-book-review-darwinshunch-science-race-and-the-search-for-human-origins/

Sussman, R.W., 2014. The Myth of Race: The Troubling Persistence of an Unscientific Idea. Harvard University Press, Cambridge.

Willis, N., 2017. Unravelling Darwin's ‘hunch'. Mail \& Guardian, 23 August. https://mg.co.za/article/2017-0823-00-unravelling-darwins-hunch

Wood, B., 2018. The complex history of human origins research in South Africa. Evolutionary Anthropology 27, 92-94.

Wolpoff, M., Caspari, R., 1997. Race and Human Evolution. Simon and Schuster, New York. 